\title{
Die bydrae en relevansie van die Nuwe- Testamentiese wetenskap in die GKSA 1869-1994
}

\author{
M.A. Kruger \\ Departement Nuwe Testament \\ Hammanskraalse Teologiese Skool/PU vir CHO \\ POTCHEFSTROOM
}

\begin{abstract}
The contribution and relevance of New Testament study in the GKSA (1869-1994)
\end{abstract}

In order to celebrate the 125th anniversary of the Faculty of Theology and of the Potchefstroom University for Christian Higher Education, which developed from this faculty, an overview of New Testament research in the Reformed Churches is given. In this article the contribution, as far as New Testament research is concerned, is described with regard to its early stages. The contribution of W.J. Snyman who gave great impetus to New Testament studies is highlighted. The contributions of his successors are also considered. Doctoral theses are mentioned by name, but seeing that the material would be too extensive for the purpose of this article, master's degrees are not mentioned. Additional New Testament contributions in which different scholars published in the same field of investigation are, however, dealt with. Because of the extensive amount of material available, articles in theological journals could only be considered in so far as trends are concerned. After an evaluation of the mentioned contributions, a cursory future perspective is given.

\section{Inleiding}

Daar is nie veel bekend van die wyse waarop die Nuwe-Testamentiese wetenskap in die kring van die GKSA beoefen is gedurende die eerste dekades na die totstandkoming van die Teologiese Skool in 1869 nie. Predikante-opleiding deur di. D. Postma en J. Beyer het reeds sedert 1863 begin (Jooste, 1959:101). 
In die leergang wat in 1869 ingestel is, was Grieks, saam met Latyn en Hebreeus, een van die verpligte vakke. Hierdie leergang wat ook Bybelse Uitlegkunde en Redekunde (Retoriek), afgesien van Homiletiek, ingesluit het (Jooste, 1959:101-102), was die begin van Nuwe-Testamentiese wetenskapsbeoefening in die Gereformeerde Kerke in Suid-Afrika (GKSA). Jooste (1959:101) stel dit dat met hierdie leergangsamestelling die voorbeeld van die Christelik-Afgeskeie Gereformeerde Kerk in Nederland se besluit van 1851 nagevolg is.

\section{Die bydrae van die Nuwe-Testamentiese wetenskaps- beoefening 1869-1994}

\subsection{Die vroegste periode}

Weens die probleme van die Gereformeerde Kerke aan die begin na 1859 , die stigting en voortbestaan van nuwe gemeentes, was daar van diepgaande wetenskapsbeoefening nie veel sprake nie. Soos die geval was met ander wetenskappe is daar op die terrein van die Nuwe-Testamentiese wetenskap veel meer gedoen deur populêre geskrifte, veral bydraes in die kerklike tydskrifte. Wat in populêre vorm gepubliseer is, was natuurlik die vrug van diepere studie deur manne soos D. Postma en J. Lion-Cachet. De Maandbode (1 April 1873 tot 1 Augustus 1894) en Het Kerkblad der Gereformeerde Kerk in Zuid-Afrika (vanaf 1 Oktober 1894) kon dus die kerke bou met stof wat eenvoudig weergegee is, maar wat tog getuig het van grondige wetenskaplike studie.

J.D. du Toit (Totius) het 'n groot bydrae gelewer met die vertaling van die Ou Testament in Afrikaans. Wat die Nuwe Testament betref, is drr. J.D. Kestell en B.B. Keet as vertalers benoem (Du Toit, 1959:156). Totius het egter Nuwe Testament gedoseer voordat W.J. Snyman beroep is. Weens die klein getal professore aan die Teologiese Skool en die doseerlas sowel as die kerklike take wat hulle moes vervul, is weinig wetenskaplike werke voor 1940 gepubliseer. Totius se studente getuig egter van sy deeglike klasaanbiedings.

In 1951 promoveer J.A. Schutte met die proefskrif Die titel Kurios by Paulus as aanduiding van Jesus aan die Universiteit van Pretoria onder professor E.P. Groenewald. Dit was die eerste doktorsproefskrif in Nuwe Testament vanuit die kring van die Gereformeerde Kerke in Suid-Afrika.

Aan die Universiteit van Pretoria behaal J. Postma in 1963 sy doktorsgraad met Die hiperbaton in die geskrifte van Paulus en Hebreërs. 


\subsection{W.J. Snyman}

In 1936 het W.J. Snyman die doktorale eksamen aan die Vrije Universiteit van Amsterdam afgelê. Weens die Tweede Wêreldoorlog en as gevolg van die feit dat sy onvoltooide proefskrif vernietig is deur 'n brand op die skip waarmee hy teruggekeer het na Suid-Afrika, het hy nooit sy proefskrif voltooi nie (Van Wyk, 1985:3-4).

Nadat professor W.J. Snyman beroep is, het 'n nuwe tydvak begin in die Nuwe-Testamentiese studie in die Gereformeerde Kerke. Toe W.J. Snyman in 1946 professor in Nuwe-Testamentiese vakke geword het, het die tyd vir groter spesialisasie aangebreek. Hoewel hy nie maklik gepubliseer het nie, was hy 'n persoon wat hard kon studeer en wat dus grondige wetenskaplike kennis aan sy studente kon oordra (P.C. Snyman, 1977:13). Die belangrikheid van eksegese was vir hom van die begin af duidelik. Sy intreerede het gevolglik ook gehandel oor "Die vryheid van eksegese" (W.J. Snyman, 1977:144-165).

Snyman (1956) het hoofsaaklik aangesluit by die rigting van Nederlandse teoloë soos Ridderbos, Grosheide en Greijdanus. Dieselfde hermeneutiek is gevolg. Wat openbaringsgeskiedenis betref, het hy ten nouste aangesluit by $\mathrm{H}$. Ridderbos. Die koninkryk is geneem as die sentrale gedagte waaromheen die vak behandel is. Dat sowel Johannes die Doper as Jesus hulle prediking begin het met die verkondiging dat die koninkryk van God naby gekom het, was vir hom die aanknopingspunt vir die behandeling van die openbaringsgeskiedenis vanuit hierdie hoek.

Hy kan as die grondlegger van die vak Openbaringsgeskiedenis van die Nuwe Testament in Suid-Afrika en van die Nuwe-Testamentiese wetenskap in die GKSA beskou word (Coetzee, 1981:4; vgl. Van Wyk, 1985:5). Hiervoor is erkenning aan hom verleen toe die Potchefstroomse Universiteit vir Christelike Hoër Onderwys in 1969 'n eredoktorsgraad aan hom toegeken het.

Sover dit eksegetiese metodes betref, het Snyman hom nie verdiep in die histories-kritiese metode wat teen die begin van sy bediening as professor baie sterk in veral Duitsland beoefen is nie. Hierdeur het hy waarskynlik 'n negatiewe invloed op die skool na hom gehad. Die bruikbaarheid van byvoorbeeld redaksiekritiek is daarom lank nie erken nie (Pelser, 1994:1). Hy het wel 'n grondige studie gemaak van groot teoloë soos Bultmann en het teenoor hulle standpunte 'n gereformeerde antwoord gegee. In kern kom dit daarop neer dat Snyman hom aan die gesag van die Skrif onder- 
werp het en nie met hoër kritiek bokant die Skrif gaan staan het nie. Die Skrif was nie maar vir hom een boek tussen baie ander, soos vir baie wat die histories-kritiese metode gevolg het nie (Van der Walt, 1973:13). Daarom het hy nie aanvaar dat die Skrif gesuiwer moes word van mitologiese elemente nie en het hy ook nie aanvaar dat die Nuwe Testament die produk van gemeenteteologie is nie. Vir hom was die Skrif openbaring van God. Sy beleid om die Skrif te verstaan kan beskryf word as: luister, luister, luister. Van 'n ander hoek af: eksegese, eksegese, eksegese. Die Skrif moes vanuit sy eie inhoud onder leiding van die Heilige Gees verstaan word en moes nie bestudeer word deur filosofiese vooropstellings wat van buite af ingedra word nie.

Die bydrae van Snyman tot die Nuwe-Testamentiese wetenskap in die GKSA kan die beste waardeer word soos dit gerubriseer is in Nuwe en ou dinge (P.C. Snyman, 1977:9-11), naamlik sy bydrae oor die Die kerk, die koninkryk, die volk en verder Preke en Skrffoordenkings. Hieruit blyk dat hy geen studeerkamerteoloog was wat teologie ter wille van akademiese belangstelling beoefen het nie, maar dat sy teologie inderdaad die kerk en die wêreld gedien het.

Dis jammer dat hy nie sy studie oor die kerk in die Nuwe Testament verder kon voer nie. Ook wat sy openbaringsgeskiedenis betref, moet gestel word dat hy nie krities genoeg was oor die naam van die vak nie, en dat hy nie oor die res van die Nuwe Testament gewerk het met dieselfde intensiteit as oor die Sinoptiese Evangelies nie. Wat die kerklike vergaderings betref, het hy waardevolle leiding gegee, veral ten opsigte van die eenheid van die kerk vanuit die Nuwe Testament, maar hy was tog ook kind van sy tyd en sterk beïnvloed deur die apartheidspolitiek.

Die volgende persone het onder W.J. Snyman gepromoveer:

W.J. van der Merwe met Die terminologie van liefde in die Nuwe Testament: 'n eksegetiese studie (1954), J.C. Coetzee met Volk en Godsvolk in die Nuwe Testament: 'n eksegetiese studie (1964), J.A. Schep met The Nature of the Resurrection: A Study of Biblical Data (1964), en L. Floor met De nieuwe exodus: Representatie en incorporatie in het Nieuwe Testament (1969b).

\subsection{Die periode van Snyman se opvolgers}

Studente wat onder Snyman gevorm is, het 'n stewige basis gehad waarop hulle verder kon studeer in die Nuwe Testament. T. van der Walt het in 
1962 aan die Theologische Hogeschool van Kampen gedoktoreer met 'n proefskrif wat allerweë as van die hoogste akademiese kwaliteit beskou is: Die koninkryk van God - naby! Eksegetiese verkennings van die toekomsperspektief van Jesus Christus volgens die getuienis van die Sinoptiese Evangelies. Hy het onder Herman Ridderbos se leiding hierdie studie voltooi. In 1969 het hy Snyman opgevolg as professor. Met sy benoeming as rektor van die Potchefstroomse Universiteit vir Christelike Hoër Onderwys in 1977 is hy opgevolg deur L. Floor wat toe reeds sedert 1965 professor in Nuwe Testament aan die Hammanskraalse Teologiese Skool was.

In 1971 word J.C. Coetzee as tweede professor in Nuwe-Testamentiese vakke aan die Teologiese Skool en Universiteit van Potchefstroom benoem.

Onder leiding van J.C. Coetzee as promotor en L. Floor as hulppromotor het 'n hele aantal studente hulle doktorsgrade voltooi: J.J. Janse van Rensburg met Die ontleding van die sintaktiese struktuur in die Griekse Nuwe Testament. Die ontwerp van 'n metode, geillustreer met Romeine 8 (1980); B.J. de Klerk met Die gesag van die prediking van die NuweTestamentiese briewe (1983); S.M. Lee met The Holy Spirit in the Johannine Writings, with Special Reference to the Relation between the Gospel of John and 1 John (1984); A.G.S. Venter met Die werk van die Heilige Gees in die opbou van die kerk volgens Handelinge (1986); D.J.W. Milne met The Law in Covenant-Historical Perspective: A Study of Romans Chapter 7 (1988); P.J. Buys met Die verhouding tussen gemeenteopbou en evangelisering: 'n Eksegetiese ondersoek na die betekenis van tersaaklike woorde in die Nuwe Testament en die implikasies daarvan vir die verhouding tussen die bewaring en die vermeerdering van die kerk (1989); en F.P. Viljoen met Die betekenis van "Psalmois, Humnois" en "Odais pneumatikais" in Kolossense 3:16 en Efesiërs 5:19 (1991).

Onder Floor het die volgende persone gepromoveer: S. Klepper met Filial Aspects of Jesus' Self-Consciousness: A Study in New Testament Christology, with Reference to the Gospel of Luke (1984); Chang-Kee Hwang met The Judgement of the Lord in the Sermon on the Mount (1985); C.J.H. Venter met Die Pauliniese paranese in Romeine 12:115:13 (1985); J.L. Venter met Die rondreisende prediker as profeet in die vroeg-Christelike kerk: 'n eksegeties-openbaringshistoriese studie (1986); A. Lindhout met Die lofsange van Maria, Sagaria en Simeon: 'n eksegetiese en openbaringshistoriese studie met besondere verwysing na 
die teologie van bevryding (1987); G.A. Lötter met Die werk van die Heilige Gees in die gelowiges volgens 2 Korintiërs (1993); en S.J. van der Merwe met 'n Prinsipiële beoordeling van radio en televisie as missionêre media in Suid-Afrika (1993). (Laasgenoemde is eerstens 'n missiologiese studie.)

J.J. Janse Van Rensburg het in 1983 professor geword en onder hom het A.H. Grove sy doktorsgraad behaal met Die selfidentifikasie van Christus in Openbaring 2 en 3 (1993).

G.J.C. Jordaan, wat in 1989 professor in Nuwe Testament geword het, en J.H. Petzer het albei onder Bruce Metzger navorsing gedoen. Eersgenoemde het onder professor J.H. Grobler (Grieks) met 'n D.Litt. gepromoveer oor 'n Beoordeling van die woordorde-variante in die manuskripte van die Griekse Nuwe Testament met besondere aandag aan die Evangelie volgens Lukas (1978). Jordaan was Petzer se promotor vir sy D.Litt. met die onderwerp Nuwe-Testamentiese tekskritiek sedert 1881 (1987). Ook M.J. du Plessis promoveer onder Jordaan met Die betekenis van episkopos, presbuteros en diakonos in die geskrifte van Ignatius (1983).

Jan Botha behaal in 1991 sy doktorsgraad onder leiding van B. Lategan (Universiteit van Stellenbosch) met Reading Romans 13. Aspects of the Ethics of Interpretation in a Controversial Text. In 1994 verskyn sy boek Subject to Whose Authority? Multiple Readings of Romans 13.

M.A. Kruger voltooi in 1983, nadat hy reeds vanaf 1978 professor in Nuwe-Testamentiese vakke aan die Hammanskraalse Teologiese Skool was, 'n proefskrif onder A.B. du Toit aan die Universiteit van Pretoria: Openbaring, geloof en geregtigheid: 'n eksegetiese ondersoek van Romeine 1-4.

T.C. Rabali voltooi in 1993 sy proefskrif The Motif of Hastening the Lord's Coming: 2 Peter 3:1-13 and Its Alleged Parallels and Background aan die Universiteit van Suid-Afrika onder leiding van professor H. Lombard. Sodoende word hy die eerste student wat sy grondslag aan die Hammanskraalse Teologiese Skool ontvang het wat 'n doktorsgraad verwerf.

\subsection{Publikasies}

In die voorgaande afdeling is proefskrifte genoem. Die aantal meestersgraadverhandelings, boeke, bydraes in versamelbundels en tydskrifartikels 
wat verskyn het uit die hand van Gereformeerde Nuwe-Testamentiese wetenskaplikes het sedert die sestigerjare dermate toegeneem dat dit ondoenlik is om hulle by die naam te noem in 'n artikel van hierdie aard. Daar is gepubliseer in Suid-Afrikaanse tydskrifte en oorsese tydskrifte. Bydraes is gelewer vir versamelwerke, sowel binnelands as buitelands. Die volle spektrum van die Nuwe-Testamentiese navorsing is gedek: Openbaringsgeskiedenis, Kanoniek, Eksegese, Hermeneutiek, Tekskritiek.

In 'n poging om enigsins 'n oorsig oor die publikasies te gee, sal verder gekonsentreer word op die gevalle waar skrywers in verskeie publikasies in een bepaalde rigting bydraes gelewer het.

\subsubsection{Kultuur-historiese agtergrond en metodologie}

'n Belangrike bydrae van S.C.W. Duvenage is Dékor van die Nuwe Testament (s.j.), 'n kultuur-historiese bydrae, die enigste van sy soort in Afrikaans tot 1994.

Reeds by die oorsig oor proefskrifte is dit duidelik dat daar sedert die begin van die tagtigerjare verskuiwing gekom het in die Nuwe-Testamentiese navorsing van teoloë van die GKSA. J.J. Janse van Rensburg se proefskrif was 'n eerste groot bydrae in hierdie rigting waarin die aksent sterker oorgegaan het na die metodologie in die Nuwe Testament. Die Nuwe-Testamentiese Werkgemeenskap van Suid-Afrika het vir hierdie beklemtoning ' $n$ belangrike stimulus gegee. Deur groter samewerking en kontak met die ander denominasies het daar ook binne die kringe van die GKSA belangstelling gekom vir die metodologiese vraagstukke wat in die tweede helfte van die sewentigerjare in Suid-Afrika sterk op die voorgrond gestel is.

Teoloë het meer onder die indruk gekom van die belangrikheid van die linguistiek. Dit is hierdie oortuiging wat reeds vroeëre teoloë gelei het tot die aksentverskuiwing vanaf die inhoud van die Bybelboeke na die bestudering van die linguistiek. Die proefskrif van Janse Van Rensburg (1980) is 'n duidelike voorbeeld van hierdie nuwe belangstelling.

Nadat diskoers-analise veral in die tagtigerjare baie prominent gefigureer het in die Nuwe-Testamentiese wetenskap in Suid-Afrika, en nadat die tekorte van die metode geblyk het, het Coetzee sy bydrae oor gedagtestruktuurontleding in 1988 geskryf. Op metodologiese gebied het hy ook reeds in 1980 Die gedagtestruktuur van I Johannes. 'n Illustrasie van die belangrikheid van struktuurontleding vir die interpretasie en 
prediking van die Nuwe Testament geskryf. Floor het op sy beurt 'n aantal bydraes oor die Hermeneutiek gelewer. (Kyk Floor, 1970; Floor et al., 1980; Floor, 1982; Floor 1987.)

J.J. Janse van Rensburg het drie handleidings vir die bestudering van Nuwe-Testamentiese Grieks geskryf $(1979,1984,1986)$. Hierdie werke het baie bygedra om die gebruik van Grieks vir predikante toegankliker te maak. Hy het ook 'n groot aandeel aan die nuwe Afrikaanse handboek vir Grieks wat saam met dosente van ander universiteite opgestel word, naamlik Grieks met begrip (Conradie et al., 1995).

Op die gebied van verskeie aspekte van die Nuwe-Testamentiese interpretasie het Botha in 1990 Sêmeion: inleiding tot aspekte van die interpretasie van die Griekse Nuwe Testament geskryf. Die heel nuutste belangstelling in Nuwe-Testamentiese kringe in Suid-Afrika, naamlik die bestudering van die sosiale omstandighede waarbinne die boeke van die Nuwe Testament tot stand gekom het en die invloed van die retoriek, vind ook reeds 'n weerspieëling in onlangs gepubliseerde artikels. Botha (1989, 1992,1993 ) het hom in die jongste tyd ook toegespits op die bestudering van retoriek en die invloed daarvan op die Nuwe Testament. Hy het ook leiding geneem by die totstandkoming van 'n onderafdeling van die NTWSA wat navorsing doen oor retoriek.

Petzer en Jordaan het waardevolle bydraes gelewer met hulle tekskritiese navorsing. Afgesien van hulle proefskrifte het hulle 'n artikel in In die Skriflig (1987) gepubliseer wat riglyne vir teoloë gee wat nie gespesialiseer is in tekskritiek nie. G.J.C. Jordaan se bydraes vertoon ook 'n verskeidenheid, maar die klem lê op sy bydrae ten opsigte van tekskritiek en ander elemente van die metodologie. J.H. Petzer het met 'n hele aantal publikasies 'n groot bydrae gelewer op die gebied van tekskritiek. Sy bekendste publikasie is seker Die teks van die Nuwe Testament (1990).

'n Aanduiding van die betrokkenheid by die modeme navorsing is ' $n$ artikel van Elma Cornelius ('n Hervormde lidmaat wat aan die Teologiese Skool Potchefstroom studeer en dosent is in Grieks aan die Universiteit) in In die Skriflig (1994:57). Dit is 'n studie in epistolografie, 'n onderwerp wat ook baie aandag ontvang het in die afgelope jare.

\subsubsection{Inhoudelike bydraes}

Coetzee se wetenskaplike bydrae op die gebied van kanoniek kan gesien word in sy inougurele rede in 1976: 'n Pleidooi vir vernuwing in die 
Besondere Kanoniek - toegelig aan die hand van die Evangelie van Johannes. In Die kanon van die Ou en Nuwe Testament, en in In Handleiding by die Nuwe Testament V (1979) het hy twee bydraes onderskeidelik oor die Heilige Gees in die geskrifte van Paulus en die eskatologie in Paulus se geskrifte bygedra. In Handleiding by die Nuwe Testament VI (Coetzee, 1984b) het hy besonder waardevolle bydraes gelewer oor die Johannesbriewe en die prediking van die boek Openbaring. Sy studie oor die Heilige Gees blyk ook in ander publikasies (Coetzee, 1994a) 'n belangrike aspek van sy wetenskaplike bydrae te wees. Indien in aanmerking geneem word dat Herman Ridderbos (1966) in sy groot werk oor Paulus nie voldoende aandag gewy het aan Paulus se teologie oor die Heilige Gees nie, is dit een van Coetzee se waardevolste bydraes. In In ons eie taal (1986) handel hy oor die Heilige Gees en vertaling. In 1987 publiseer hy in Skrif en Kerk die artikel "Satan en sy magte in die Nuwe Testament - besonderlik teenoor die Heilige Gees". Ook wat die diakonale amp betref, het hy ' $n$ besondere bydrae gelewer met twee bydraes in In die Skriflig (Coetzee, 1967a.:50-53; Coetzee, 1967b: 44-50).

Floor is ' $n$ baie vrugbare skrywer. Dit is opvallend hoeveel hy oor die koninkryk van God geskryf het. Nadat hy in 1969 geskryf het oor Die diaken in die Koninkryk van God, volg Die koninkryk van God in die Nuwe Testament (1969) saam met W.J. Snyman en in 1974 Die koninkryk van God en die vernuwing van die maatskappy. Dit is waarskynlik hierdie voorwerk wat gelei het tot die publikasie van wat beskou word as sy beste boek, naamlik Die evangelie van die Koninkryk (1981). Hierna het nog gevolg Koninkryk en politiek (1985). Ook aan die plek en werk van die Heilige Gees het hy besondere aandag gegee (Floor, 1987a; 1989). Omdat hy ook sendingkundige is, het hy in verskeie geskrifte die lig van die Nuwe Testament laat val op missionêre probleme (Floor, 1964; 1971; $1981 \mathrm{~b} ; 1990 \mathrm{a})$. Uit die groot getal boeke wat hy geskryf het, word die kommentaar op Jakobus (1992) ook as 'n besondere hoogtepunt beskou. Sy geskrifte is sterk ingestel op diens aan die kerk van die Here.

Janse van Rensburg se gepubliseerde artikels vertoon 'n wye veld van belangstelling en bekwaamheid. In 1993 het hy professor Wayne A. Meeks (Nuwe Testament, Yale Universiteit) as navorsingsgenoot met behulp van die ondersteuning van die INO na Suid-Afrika genooi. Hulle het gewerk aan 'n projek onder die tema "The Formation of Morality in Early Christianity". By hierdie projek het hy ook agtien kollegas van SuidAfrikaanse universiteite betrek. 


\subsubsection{Tydskrifartikels}

'n Groot verskeidenheid artikels wat die metodologie sowel as die inhoud van die boeke van die Nuwe Testament dek, is gepubliseer. Veral in In die Skriflig en Neotestamentica is artikels gepubliseer. 'n Noemenswaardige getal publikasies het ook in oorsese tydskrifte verskyn. 'n Aantal artikels oor indikatief en paraklese in die boeke van die Nuwe Testament (In die Skriflig, 24(1), 1990; 24(2), 1990) is karakteriserend van die meeste van die artikels. Hierdie bydraes is duidelik gerig daarop dat dit diensbaar moet wees aan die prediking (vgl. Floor, 1990:155-165; Janse van Rensburg, 1990:71-101; Jordaan 1990:49-69; Kruger, 1990:27-40; Venter, 1990:1-26).

\subsection{Werkgemeenskappe}

W.J. Snyman, T. van der Walt en J.C. Coetzee was van die stigterslede van die Nuwe-Testamentiese Werkgemeenskap van Suid-Afrika. Tans is al die professore (met die uitsondering van Floor) en Gereformeerde gedoktoreerdes in Nuwe Testament nog lede van hierdie werkgemeenskap. Veral J.J. Janse van Rensburg neem 'n groot aandeel in die werksaamhede as tweede hoofsekretaris. Hy is ook lid van die Suid-Afrikaanse Vereniging vir Patristiese en Bisantynse Studies.

Van Rensburg, Jordaan en Petzer is ook lede van die internasionale Society of Biblical Literature. Coetzee is lid van die Studiorum Novi Testamenti Societas. In 1984 is die Gereformeerde Nuwe-Testamentiese Werkgemeenskap van Potchefstroom gestig waarvan al die Nuwe Testament-dosente te Potchefstroom lede is.

\subsection{Gasdosente en oorsese besoeke}

Veral Floor en Coetzee het by verskeie geleenthede as gasdosente in verskillende wêrelddele opgetree. Ten tyde van die skrywe van hierdie artikel was Coetzee in België waar hy vir 'n aantal weke sou doseer. Hy het gedurende 'n wêreldwye reis in 1975 (om koördinasie tussen inrigtings vir Christelike Hoër Onderwys te bevorder) op vyf-en-vyftig plekke met openbare voordragte opgetree of deelgeneem aan internasionale byeenkomste.

Floor het vanaf 1977 tot 1993 in Nederland, Brazilië, Suid-Korea en België op uitnodiging as gasdosent opgetree.

Kruger het in 1986 met 'n voordrag by die Leuvense Bijbelstudie-dagen opgetree. 


\subsection{Bybelvertaling}

Op verskillende vlakke is Gereformeerde Nuwe-Testamentici betrek by Bybelvertaling. T. van der Walt en J. Postma het meegewerk aan die jongste Afrikaanse vertaling. Op die eindredaksie het Van der Walt en Coetzee gedien. Coetzee, Kruger, Janse Van Rensburg en Jordaan het meegewerk aan die Verwysingsbybel. Janse Van Rensburg dien ook op die redaksiekomitee van hierdie Bybel. Janse van Rensburg het 'n reuseaandeel gehad in die voorbereiding van Die Bybel in praktyk, naamlik as redakteur van die Nuwe Testament; hy was verantwoordelik vir een-derde van die Nuwe Testament.

\subsection{Radio}

Verskeie Gereformeerde professore in Nuwe Testament het van tyd tot tyd deelgeneem aan Bybel-besprekingsprogramme oor die Afrikaanse radiodiens. Die voorbereiding vir die programme het deeglike wetenskaplike voorbereiding geverg, hoewel dit populêr aangebied is.

\section{Die relevansie van die Nuwe-Testamentiese bydrae uit die GKSA}

\subsection{Grondslag}

Die grondslag van die Gereformeerde Nuwe-Testamentiese studie in SuidAfrika is gelê soos die erfenis van gereformeerde teologie vanaf Nederland hierheen oorgekom het. Tot diep in die sestigerjare is daar feitlik geen verskil gevoel tussen die gereformeerde lyn in Suid-Afrika en in Nederland nie. Dit was eers met die verreikende standpunte van Kuitert en Wiersenga dat daar in Suid-Afrika teologies wegbeweeg is van die groot afhanklikheid van Nederland.

Op die gebied van die Nuwe Testament het die werke van Herman Ridderbos, F.W. Grosheide en S. Greijdanus groot invloed uitgeoefen. Die kommentaar-reekse van Calvyn en Kommentaar op het Nieuwe Testament sowel as Korte Verklaring dui die tipe Nuwe-Testamentiese teologie van 'n groot deel van hierdie eeu aan. Tog is daar algemeen gebruik gemaak van meer kritiese kommentare soos die International Critical Commentary.

Die Bybel as gesaghebbende en geinspireerde Woord van God is deur teoloë aanvaar. Somtyds het daar wel fundamentalistiese trekke deurgewerk: daar is byvoorbeeld nie gevra na die aard van die inspirasie nie. Ook was 
daar ' $n$ tendens om die foutloosheid van die teks (die outograwe) te vereenselwig met onfeilbaarheid van die Skrif.

\subsection{Metodologie}

Deur die streng afwysing van die histories-kritiese metode is daar dikwels te reaksionêr gehandel deur Gereformeerde Nuwe-Testamentici. Dikwels is die histories-kritiese metode simplisties vereenselwig met hoër kritiek en is die dienende funksie daarvan nie raakgesien nie. Eers in die jongste tyd het byvoorbeeld redaksiekritiek en vormkritiek ' $n$ rol begin speel in die gereformeerde beoefening van die wetenskap. Die gevolg van hierdie afsydigheid was dat daar hoofsaaklik vasgehou is aan die grammaties-historiese metode alleen as wyse van Skrifverklaring. Pelser (1994), byvoorbeeld, sê dat Gereformeerdes op 'n fundamentalistiese, konfessiebepaalde wyse met die Skrif gewerk het.

Dit is 'n vraag of die inspirasie van die Skrif nie by sommige teoloë in die GKSA te veel vereenselwig is met die foutloosheid van die Skrif nie, en of daar nie met 'n na-reformatoriese en meer rigoristiese beeld van die belydenisskrifte gewerk is nie, byvoorbeeld oor die aanvaarding van 'n kanon wat geslote is, sonder dat artikel 5 NGB in sy konteks verstaan word (vgl. Pelser, 1994:2).

Daar is 'n voordeel verbonde aan hierdie konserwatiwiteit van die GKSA. Byna elke nuwe navorsingsrigting wat bestudeer word vir die verstaan van die Nuwe Testament is reeds in 'n mate in die grammaties-historiese metode ingesluit. Deur spesialisasie word daar egter aan elemente wat reeds deur hierdie metode gebruik is, groot prominensie gegee. Dit het weer tot gevolg dat Nuwe-Testamentici dikwels die Nuwe Testament sterk deur die filter van een aspek gekleur sien en dat die organiese totaalkarakter van 'n geskrif nie gesien word nie. As voorbeelde kan die volgende dien: 'n Aantal jare gelede is diskoers-analise so beklemtoon dat dit heeltemal oordryf is. Daarna het epistolografie, retoriek en die sosiale konteks gevolg. Gevolglik kan 'n geweldige verskraling van die Skrifinhoud plaasvind wanneer deur so 'n enkele filter na 'n geskrif gekyk word. Hierdie benadering bring ook oorspesialisasie mee wat die werk vir die kerk feitlik onbruikbaar maak. Hierdie verwyte is inderdaad uitgespreek teenoor die Nuwe-Testamentiese teoloë. Daar is by die oorbeklemtoning van die metodologie 'n wesenlike gevaar dat die primêre bronne, die boeke van die Nuwe Testament, nie meer goed bestudeer word in hulle totaliteit nie. 
Die Gereformeerde Kerke se teoloë was wel traag om met al die nuwe rigtings saam te gaan en het daardeur 'n verlies gely. Aan die ander kant het hulle egter gewoonlik die nuwe rigtings in die metodologie versigtig ingebed in die beproefde metodes wat die kerk deur die eeue ontwikkel het. Daarmee het hulle daarin geslaag om die geskrifte beter in hulle volle betekenis te laat spreek vir 'n gehoor, naamlik die kerk en die wêreld. Die werkwyse van GKSA toeloë was nie akademiese werk uit 'n akademiese ivoortoring nie. Die GKSA het myns insiens altyd die weg (probeer) volg om die nuwe in te bed in die oue. Hulle het die regula fidei gevolg (altans probeer volg), terwyl die teologie van die Protestantse Weste en in SuidAfrika dikwels gebaseer is op die Griekse model wat vra: 'Wat is nuut?' en 'Wat is mode?' (Hand. 17:21).

\subsection{Diens aan ander dissiplines}

Gereformeerde Nuwe-Testamentici het nie heeltemal daarin geslaag om suiwerend in te werk op die tradisionele Skrifgebruik veral in Dogmatiek en Kerkreg nie. Verkeerde gebruike wat oorgeërf is vanaf die gereformeerde Kerke in Nederland is vandag feitlik nog net so in swang. Voorbeelde van die verkeerde gebruik is die aanwending van die tradisionele verklarings van die perikoop Matteus 18:15 en verder en 1 Timoteus 5:17 in die Kerkreg. In hierdie tradisionele verklarings word op 'n onhoudbare wyse onderskei tussen openbare sondes en heimlike sondes (Kruger, 1992:7587). In die dogmatiek word Romeine misbruik deur die afleiding dat die sogenaamde algemene openbaring nie genoegsaam is vir saligmakende kennis nie; en Romeine 10:17 wat losgemaak word van sy konteks en veral van die volgende vers wat aanhaal uit Psalm 19 (Kruger, 1988:81-97).

\subsection{Diensbaarheid aan die kerk}

Talle studies is in opdrag van sinodes en ander meerdere vergaderings gemaak om Bybelse lig te laat val op praktiese probleme wat in die kerke ontstaan het. Drie belangrike voorbeelde hiervan is die studie met die oog op die rasseverhoudinge binne die kerke, die diakonale diens en die posisie van die vrou ten opsigte van die besondere ampte. Hierdie studies het die kerk gehelp om nie deur die strominge van die wêreld meegesleur te word nie. Tog moet by al die pogings wat aangewend is om regverdige rasseverhoudinge te vind, die feit gekonstateer word dat foute begaan is en dat die Nuwe Testament ook verkeerdelik as bewysbron gebruik is aangesien dit soms deur die bril van rassevooropstellings en fundamentalisme gelees is. 
Die nou verband wat daar tussen kerk en teologie was, het dikwels die program van Nuwe-Testamentiese navorsing bepaal. Hierdie lewende band tussen kerk en Nuwe-Testamentiese navorsing moet as een van die grootste bates van die Nuwe-Testamentiese wetenskap in die GKSA gewaardeer word. Van die beste bydraes van Nuwe-Testamentici is gelewer in rapporte wat vir sinodes voorberei is.

\subsection{Gerigtheid na buite}

Hoewel die GKSA altyd die eenheid van die kerk in al die gelowiges bely het, moet daar tog erken word dat ons soms kerkisties en na binne gekeer was (vgl. Pelser, 1994:3). Tog blyk uit 'n oorsig dat daar wêreldwyd uitbeweeg is. Teenoor ' $n$ tendens om in tradisionalisme vas te val, moet daar steeds hierdie wisselwerking met die wêreld wees, anders gaan die kerk ten gronde. In ons tyd is die slagspreuk beslis nie dat ons behoud in isolasie lê nie. In isolasie kan 'n kerk ook sektaries word.

\section{Toekomsperspektiewe}

\subsection{Die band tussen die kerk en die Nuwe-Testamentiese na- vorsing}

Dit moet steeds as die hoogste prioriteit van die Nuwe-Testamentiese navorsing in die GKSA gesien word dat dit die kerk, en so die Here van die kerk en sy koninkryk moet dien. Navorsing ter wille van navorsing alleen, kan nooit die doel van die Nuwe-Testamentiese wetenskap wees nie.

Die diensbaarheid van die Nuwe-Testamentiese wetenskap aan die kerk kan egter verminder as die klem te ongebalanseerd op die metodologiese aspek gaan val. By sommige denominasies is dit reeds die geval dat die verband tussen wetenskapsbeoefening en die kerk erg geskaad is, byvoorbeeld in die Lutherse teologie van Duitsland. Ook ander dissiplines kan nie voordeel trek uit die navorsing indien daar so 'n oorspesialisasie in die metodologie en 'n onderspesialisasie in die primêre geskrifte van die Nuwe Testament is nie.

\subsection{Die Nuwe Testament en hedendaagse probleme}

Die navorsing van die Nuwe Testament moet toespits op die probleme van ons eie tyd. Enkele van hierdie probleme wat nou, of wéer, aktueel geword het, is die volgende:

- Ekologie. 
- Die verhouding man/vrou in die algemeen en in die kerk.

- Die volkere- en rassesituasie in die wêreld.

- Die verskeidenheid van sogenaamde teologieë.

- Die Kerkorde en die Nuwe Testament.

- Die Nuwe Testament en ekumeniese verhoudinge.

- Die media in die lig van die Nuwe Testament.

- Die viering van die Nagmaal.

- Liturgiese vernuwing.

- Kerkgroei (die uitbreiding van die koninkryk van God, al is dit nie identies met kerkgroei nie).

Van hierdie studierigtings behoort die problematiek rondom man en vrou in die huwelik en die vrou se rol in die kerk, die viering van die Nagmaal, liturgiese vernuwing en ' $n$ verdere bestudering van ras en volk dringende aandag te kry.

\subsection{Kommentare en handboeke}

'n Wesenlike behoefte is die skryf van kommentare wat ten eerste diensbaar moet wees aan die bedienaars van die Woord. Nuwe metodes en nuwe inligting moet neerslag vind in sulke kommentare. Dit is byvoorbeeld deur nuwere studie duidelik dat 'n boek soos Romeine as gevolg van die konflik tydens die Reformasie te veel deur die filter van hierdie konflik gelees is en dat dit vandag vir die huidige probleme in die wêreld veel te sê het as dit volledig ontsluit word. Tot sover is in Afrikaans nog weinig kommentare geskryf vanuit die geledere van die GKSA. P.J.S. de Klerk het 'n kommentaar oor Hebreërs gepubliseer, maar verder is dit slegs Floor wat kommentare in Nederlands laat verskyn het.

Verskeie Nuwe-Testamentici het meegewerk aan handboeke vir die bestudering van die Nuwe Testament. Afgesien van verskeie skoolboeke, is daar ook sulke werke vir gevorderde studie soos die reeks Handleiding $b v$ die Nuwe Testament. Samewerking met teoloë wat nie van die GKSA is nie, is belangrik want dit verhoed dat daar isolasie en stagnering kom. Dit sou goed wees as die Nuwe-Testamentici van die GKSA meer handboeke kon publiseer. 


\subsection{Navorsing en doseerwerk}

Terwyl die navorsers 'n lewende band met die kerk moet hê en hulle navorsing die kerk moet dien, moet daar tog 'n balans gehandhaaf word sodat navorsers, veral die dosente in Nuwe Testament, genoeg tyd en middele het om hul steeds dieper in te grawe om die Nuwe-Testamentiese verkondiging vir die kerk te laat oopgaan.

\section{Bibliografie}

BOTHA, J. 1989. On the 'Reinvention' of Rhetoric. Scriptura, 31:41-31.

BOTHA, J. 1990. Semeion. Inleiding tot aspekte van die interpretasie van die Nuwe Testament. Pretoria : N.G. Kerkboekhandel.

BOTHA, J. 1991. Reading Romans 13. Aspects of the Ethics of Interpretation in a Controversial Text. Stellenbosch : Universiteit van Stellenbosch. (D.Th. Thesis.)

BOTHA, J. 1992. Creation of New Meaning: Rhetorical Situations and the Reception of Romans 13:1-7. Journal for Theology in Southern Africa, 79:24-37.

BOTHA, J. 1993. Aspects of the Rhetoric of South African New Testament Scholarship anno 1992. Scriptura, 46:80-99.

BOTHA, J. 1994. Subject to Whose Authority? Multiple Readings of Romans 13. Atlanta : Scholars Press.

BUYS, P.J. 1989. Die verhouding tussen gemeente-opbou en evangelisering. 'n Eksegetiese ondersoek na die tersaaklike woorde in die Nuwe Testament en die implikasies daarvan vir die verhouding tussen die bewaring en vermeerdering van die kerk. Potchefstroom : PU vir CHO. (Th.D.-proefskrif.)

CHANG-KEE, Hwang. 1985. The Judgement of the Lord in the Sermon on the Mount. Potchefstroom : PU vir CHO. (Th.D.-proefskrif.)

COETZEE, J.C. 1964. Volk en Godsvolk in die Nuwe Testament : 'n eksegetiese studie. Potchefstroom : Pro Rege.

COETZEE, J.C. 1967a. Die begrip "Diakonos" as aanduiding van 'n besondere ampsdraer. In die Skriflig, 1(4):50-53.

COETZEE, J.C. 1967b. Enkele Skrifgegewens oor die diakenamp - Handelinge 6 en die diakenamp. In die Skriflig, 1(4):44-50.

COETZEE, J.C. 1976. 'n Pleidooi vir vernuwing in die Besondere Kanoniek toegelig aan die hand van die Evangelie van Johannes. Potchefstroom : PU vir CHO. (Inougurele rede).

COETZEE, J.C. 1979. Die kanon van die Ou en Nuwe Testament. Potchefstroom : Pro Rege. 
COETZEE, J.C. 1980. Die gedagtestruktuur van 1 Johannes. 'n Illustrasie van die belangrikheid van struktuurontleding vir die interpretasie en prediking van die Nuwe Testament. Potchefstroom : PU vir CHO. (Wetenskaplike Bydraes van die PU vir CHO. Reeks A. Geesteswetenskappe. No. 36.)

COETZEE, J.C. 1981. "Prof Willie"/"Oom Willie": Prof. W.J. Snyman as leermeester en wetenskaplike. Die Kerkblad, 84(2609):3-4, Julie.

COETZEE, J.C. 1984a. Die Heilige Gees en die prediking van Paulus. (In Botha, F.J. e.a. red. Handleiding by die Nuwe Testament V. Pretoria : N.G. Kerkboekhandel. p. 234-245.)

COETZEE, J.C. 1984b. Paulus se eskatologiese prediking. (In Botha, F.J. e.a. red. Handleiding by die Nuwe Testament V. Pretoria : N.G. Kerkboekhandel. p. 332-362.)

COETZEE, J.C. 1986. Die Heilige Gees in vertaling. (In Van der Walt, J.J. red. In ons eie taal. Potchefstroom : Sentrale Publikasies. p. 165-174.)

COETZEE, J.C. 1987. Satan en sy magte in die Nuwe Testament - besonderlik teenoor die Heilige Gees. Skrif en Kerk, 8(1):20-37.

COETZEE, J.C. 1988. Gedagtestruktuurontleding en die eksegese van die Heilige Skrifte. (In Coetzee, J.C. red. Koninkryk, Gees en Woord. Pretoria : N.G. Kerkboekhandel. p. 19-37.)

CONRADIE, P. e.a. red. 1995. Grieks met begrip. 'n Inleidende grammatika, toegespits op die Griekse Nuwe Testament. Aucklandpark : Werkgroep vir Griekse Onderrig.

CORNELIUS, Elma 1994. The Function of the Topos philophronesis in the Letter to the Philippians - A Comparison with Three Ancient Letters of Friendship. In die Skriflig, 28(1) 57-74.

DE KLERK, B.J. 1983. Die gesag van die prediking van die Nuwe-Testamentiese briewe. Potchefstroom : PU vir CHO. (Th.D.- proefskrif.)

DE KLERK, P.J.S. 1951. Die brief aan die Hebreërs. Pretoria : Van Schaik.

DU PLESSIS, M.J. 1983. Die betekenis van episkopos, presbuteros en diakonos in die geskrifte van Ignatius. Potchefstroom : PU vir CHO. (Th.D.proefskrif.)

DU TOIT, S. 1959. Die Gereformeerde Kerk en die vertaling van die Bybel, die beryming van die kerklied en kanttekeninge. (In Van der Vyver, G.C.P. e.a. red. Die Gereformeerde Kerk in Suid-Afrika 1859-1959. Potchefstroom : Die Kerkblad. p. 151-169.)

DUVENAGE, S.C.W. s.j. Dékor van die Nuwe Testament. Pretoria : Interkerklike Uitgewerstrust.

FLOOR, L. 1964. In dieselfde spore, 'n ondersoek na die struktuur van die sending. Potchefstroom : Die Evangelis.

FLOOR, L. 1969a. Die plek van die diaken in die Koninkryk van God. (In Du Toit, S. e.a. red. Die koninkryk van God. Potchefstroom : Pro Rege. p. 34-246.) 
FLOOR, L. 1969b. De nieuwe exodus: Representatie en incorporatie in het Nieuwe Testament. Potchefstroom : PU vir CHO. (Th.D.-proefskrif.)

FLOOR, L. 1970. Calvyn se hermeneutiek en sy betekenis vir ons tyd. In die Skriflig, 4(14):3-20, Junie.

FLOOR, L. 1971. The Lord and the Holy Spirit in the Fourth Gospel. The Christ of John, Essays on the Christology of the Fourth Gospel. Neotestamentica, 2:122-130.

FLOOR, L. 1974. Die Koninkryk van God en die vernuwing van die maatskappy. Potchefstroom : RGN Publikasie-reeks no.50.

FLOOR, L. 1979. Hy wat met die Heilige Gees doop. Pretoria : N.G. Kerkboekhandel.

FLOOR, L. 1981a. Die evangelie van die Koninkryk. Pretoria : N.G. Kerkboekhandel.

FLOOR, L. 1981b. Die missionêre karakter van die kerk. (In Van der Walt, I.J. red. Kerk en wêreld. Noordbrug : CJBF. p. 44-56.)

FLOOR, L. 1982a. De doop met de Heilige Geest. Kampen : Kok.

FLOOR, L. 1982b. The hermeneutics of Calvin. (In Calvinus Reformator. His Contribution to Theology, Church and Society. Potchefstroom : IRS. p. 181-191.) ("Wetenskaplike Bydraes" of the PU for CHE, Serie F: Institute for Reformational Studies F3 Collections, Number 17, PU for CHE.)

FLOOR, L. 1985. Koninkryk en politiek. (In Van Wyk, J.H. red. Altyd reformeer. Gesprekke oor politiek en godsdiens. Braamfontein : Boekhandel De Jong. p. 94-99.)

FLOOR, L. 1986. De relatieve zelfstandigheid van de Heilige Gees. Koers, 53(3):375-405.

FLOOR, L. 1987a. Die Heilige Gees en die prediking. In die Skriflig, 21(81): 8-18, Maart.

FLOOR, L. 1987b. Teologiese hermeneutiek. (In Duvenage, B. red. Paradigmas in die wetenskappe, 'n Christelike perspektief. Potchefstroom : Dept. Wetenskapsleer. p. 86-91.)

FLOOR, L. 1990a. Die missionêre gemeente. (In Denkema, F. e.a., red. Evangeliseer! Pretoria : N.G. Kerkboekhandel. p. 94-100.)

FLOOR, L. 1990b. Die verhouding tussen indikatief en paraklese in die Nuwe Testament toegelig vanuit die eerste brief aan die Tessalonisense. In die Skriflig, 24(2):155-165.

FLOOR, L. 1992. Jakobus, Brief van een broeder. (In Van Bruggen, J. red. Commentaar op het Nieuwe Testament, Derde serie. Kampen : Kok.)

FLOOR, L., COETZEE, J.C. \& DE KLERK, B.J. 1980. Die hermeneuse van die Skrif. Koers, 45(1):18-36.

FLOOR, L. \& SNYMAN, W.J. 1969. Die koninkryk van God in die Nuwe Testament. (In Du Toit, S. e.a. red. Die koninkryk van God. Potchefstroom : Pro Rege Pers Bpk. p. 34-58.) 
GROVE, A.H. 1993. Die selfidentifikasie van Christus in Openbaring 2 en 3. Potchefstroom : PU vir CHO. (Ph.D.-proefskrif.)

JANSE VAN RENSBURG, J.J. 1979. Paidagogos; 'n werkboek en gids vir Grieks I-studente. Potchefstroom : Wesvalia.

JANSE VAN RENSBURG, J.J. 1980. Die ontleding van sintaktiese struktuur in die Griekse Nuwe Testament. Die ontwerp van 'n metode geillustreer met Romeine 8. Frankfort : Fiksona.

JANSE VAN RENSBURG, J.J. 1984. 'n Sintaktiese model as basis en raamwerk vir die onderrig van Grieks aan voomemende predikante. Potchefstroom : PU vir CHO.

JANSE VAN RENSBURG, J.J. 1986. Grammatikos; 'n Handleiding by grammatiese eksegese van die Griekse Nuwe Testament. Potchefstroom : PU vir CHO.

JANSE VAN RENSBURG, J.J. 1990. Indikatief en paraklese in 1 Petrus. In die Skriflig, 24(1): 71-101.

JANSE VAN RENSBURG, J.J. 1993. A New Reference Grammar for the Greek New Testament: Exploratory Remarks on a Methodology. Neotestamentica, 27 (1):133-152.

JOOSTE, J.P. 1959. Die ontstaan en die geskiedenis van die Teologiese Skool. (In Van der Vyver, G.C.P. e.a red. Die Gereformeerde Kerk in SuidAfrika 1859-1959. Potchefstroom : Die Kerkblad. p. 98-109.)

JORDAAN, G.J.C. 1978. 'n Beoordeling van die woordordevariante in die manuskripte in die Griekse Nuwe Testament met besondere aandag aan die Evangelie volgens Lukas. Potchefstroom : PU vir CHO. (D.Litt.-proefskrif.)

JORDAAN, G.J.C. 1990. Die verhouding tussen indikatief en paraklese in Efesiërs. In die Skriflig, 24(1):49-69.

KLEPPER, S. 1984. Filial Aspects of Jesus' Self-consciousness: A Study in New Testament Christology, with Reference to the Gospel of Luke. Potchefstroom : PU vir CHO. (Th.D.-proefskrif.)

KRUGER, M.A. 1983. Openbaring, geloof en geregtigheid. 'n Eksegetiese ondersoek van Romeine 1-4. Pretoria : Universiteit van Pretoria. (D.D.proefskrif.)

KRUGER, M.A. 1988. Naby jou is die Woord - Romeine 10:8. (In Coetzee, J.C. red. Koninkryk, Gees en Woord, huldigingsbundel aangebied aan prof. dr. Lambertus Floor. Pretoria : NG Kerkboekhandel. p. 81-97)

KRUGER, M.A. 1990. Indikatief en paraklese in Romeine. In die Skriflig, 24(1):27-48.

KRUGER, M.A. 1992. 'n Skriftuurlike evaluering van artikels $72-76$ van die Kerkorde van die GKSA. In die Skriflig, 26(1):75-87.

LEE, S.M. 1984. The Holy Spirit in the Johannine Writings, with Special Reference to the Relation between the Gospel of John and 1 John. Potchefstroom : PU vir CHO. (Th.D.-proefskrif.) 
LINDHOUT, A. 1987. Die lofsange van Maria, Sagaria en Simeon: 'n eksegetiese en openbaringshistoriese studie met besondere verwysing na die Teologie van Bevryding. Potchefstroom : PU vir CHO. (Th.D.-proefskrif.) LOTTER, G.A. 1993. Die werk van die Heilige Gees in die gelowiges volgens 2 Korintiërs. Potchefstroom : PU vir CHO. (Th.D.-proefskrif.)

MILNE, D.J.W. 1988. The Law in Covenant-Historical Perspective: A Study of Romans Chapter 7. Potchefstroom : PU vir CHE. (Th.D. Thesis.)

PELSER, G.M.M. 1994. Evaluering van 'n aantal bydraes gelewer deur Gereformeerde Nuwe-Testamentici oor die afgelope dekades. Ongepubliseerde artikel.

PETZER, J.H. \& JORDAAN, G.J.C. 1987. New Testament Textual Criticism for Non-textual Critics. A Few Suggestions. In die Skriflig, 21(84):43-47. PETZER, J.H. 1987. Nuwe-Testamentiese tekskritiek sedert 1881. Potchefstroom : PU vir CHO. (Th.D.-proefskrif.)

PETZER, J.H. 1990. Die teks van die Nuwe Testament. (Supplementum 2 van Hervormde Teologiese Studies)

POSTMA, J. 1963. Die hiperbaton in die briewe van Paulus en Hebreërs. Pretoria : Universiteit van Pretoria.

RABALI, T.C. 1993. The Motif of Hastening the Lord's Coming. 2 Peter 3:113 and Its Alleged Parallels and Background. Pretoria : Unisa. (D.Th. Thesis.)

RIDDERBOS, H. 1966. Paulus. Ontwerp van zijn theologie. Kampen : Kok.

SCHEP, J.A. 1964. The Nature of the Resurrection: A Study of Biblical Data. Grand Rapids : Eerdmans.

SCHUTTE, J.A. 1951. Die titel Kurios by Paulus as aanduiding van Jesus. Potchefstroom : Pro Rege.

SNYMAN, P.C. 1977. Uit die lewe van prof. Snyman. (In Snyman, P.C. red. Nuwe en ou dinge. "Uit die skat van die koninkryk". Potchefstroom : Pro Rege. p. 13-16.)

SNYMAN, W.J. 1956. Diktaat Hermeneutiek van die Nuwe Testament. Potchefstroom : Pro Rege-Pers Beperk.

SNYMAN, W.J. 1977. Die vryheid van eksegese. (In Snyman, P.C. red. Nuwe en ou dinge. "Uit die skat van die koninkryk. Potchefstroom : Pro Rege. p. 144-165.)

VAN DER MERWE, S.J. 1993. 'n Prinsipiële beoordeling van die radio en televisie as missionêre media in Suid-Afrika. Potchefstroom : PU vir CHO. (Th.D.-proefskrif.)

VAN DER MERWE, W.J. 1954. Die terminologie van die liefde in die Nuwe Testament : 'n eksegetiese studie. Potchefstroom : PU vir CHO. (Th.D.proefskrif.)

VAN DER WALT, T. 1962. Die koninkryk van God - naby! Eksegetiese verkennings van die toekomsperspektief van Jesus Christus volgens die getuienis van die Sinoptiese Evangelies. Kampen : Kok. 
VAN DER WALT, T. 1973. 'n Eerste inleiding in die eksegese en hermeneutiek van die Nuwe Testament. Klasdiktaat.

VAN WYK, J.H. 1985. Man van die derde weg. W.J. Snyman as teoloog. Potchefstroom : PU vir CHO.

VENTER, A.G.S. 1986. Die werk van die Heilige Gees in die opbou van die kerk volgens Handelinge. Potchefstroom : PU vir CHO. (Th.D.-proefskrif.)

VENTER, C.J.H. 1985. Die Pauliniese paranese in Romeine 12:1-15:13. Potchefstroom : PU vir CHO. (Th.D.-proefskrif.)

VENTER, C.J.H. 1990. Indikatief en paraklese in die Pastorale Briewe. In die Skriflig, 24(1):1-26.

VENTER, J.L. 1986. Die rondreisende prediker as profeet in die vroeg-Christelike kerk: 'n eksegeties-openbaringshistoriese studie. Potchefstroom : PU vir CHO. (Th.D.-proefskrif.)

VILJOEN, F.P. 1991. Die betekenis van "Psalmois, Humnois" en "Odais pneumatikais" in Kolossense 3:16 en Efesiërs 5:19. Potchefstroom : PU vir CHO. (Th.D.-proefskrif.) 
